\title{
Bagaimana Perusahaan Mengukur Kinerjanya
}

\author{
Cahyo Adityo Irawan
}

S130118033@ubaya.student.ac.id

Kinerja oleh Perusahaan (Performance) diukur dengan Return on Assets (ROA), Tobin's Q (TOBINSQ) dan Return on Equity (ROE). Return on Assets adalah laba sebelum bunga dan pajak dibagi dengan nilai buku total aset, Tobin's $Q$ adalah nilai pasar ekuitas dan nilai buku kewajiban, yang semuanya dibagi dengan total aset dan Return on Equaity adalah laba bersih dibagi total ekuitas (Harymawan, Agustia, Nasih, Azmi Inayati, \& Nowland, 2020).

Konsep yang berbeda digunakan dalam literatur untuk mengukurnya seperti: produktivitas (nilai tambah, output bruto, perputaran per karyawan), pertumbuhan (pertumbuhan penjualan atau omset), pertumbuhan lapangan kerja dan ukuran keuangan perusahaan (margin operasi, laba atas penjualan, Tobin’s Q). (Madaleno, Robaina, Ferreira Dias, \& Meireless, 2019). Alasan keputusan bahwa dalam mengukur kinerja perusahaan seperti menggunakan ROA, ROE atau pertumbuhan total aset, aset bersih atau laba adalah karena berkaitan tentang kegiatan akuntansi, terutama bagaimana kinerja perusahaan swasta dalam pertumbuhan ekonomi (Osiyevskyy, Shirokova, \& Ritala, 2020)

Dalam Pratono 2016, Penelitian mengadopsi pendekatan kontingensi untuk memahami dampak SO terhadap kinerja UKM dalam konteks TT dinamis. Adanya teori tersebut dimaksudkan sebagai kritik teori manajemen klasik karena mengabaikan faktor kontingensi. Telah diakui bahwa baik Max Weber dengan teori birokrasinya maupun Frederic Taylor dengan teori manajemen ilmiahnya terlalu memperhatikan internal organisasi. Premis dasar teori kontingensi adalah bahwa perusahaan mencapai kinerja terbaiknya saat struktur mereka relevan untuk menangani kontinjensi yang dipaksakan oleh ukuran, teknologi, dan juga oleh lingkungan mereka (Pratono H. A., 2016)

Dalam Pratono 2019, perusahaan mengadopsi pendekatan orientasi pasar yang responsif untuk memenuhi kebutuhan pelanggan. Perusahaan dapat mempercayai peran orientasi pasar, tetapi mereka mungkin mengalami kekurangan kemampuan untuk mencapai kinerja yang diharapkan melalui orientasi pasar. Kesenjangan antara kesadaran lingkungan konsumen dan perilaku konsumen dapat terjadi ketika banyak perhatian pada konsumen berkelanjutan diikuti oleh sensitivitas harga konsumen untuk pembelian ramah lingkungan. Berbagai tingkat dampak orientasi kewirausahaan pada keunggulan kompetitif perusahaan yang berkelanjutan membutuhkan penyelidikan lebih lanjut, yang mungkin melibatkan variabel mediasi untuk menjelaskan hubungan yang kompleks. Penelitian ini bertujuan untuk menguji peran pembelajaran antar organisasi dalam mentransformasikan orientasi pasar untuk peningkatan keunggulan kompetitif berkelanjutan. Persamaan struktural dikembangkan untuk menjelaskan hubungan rumit antara orientasi Green Enterpreneurial, orientasi pasar dan keunggulan kompetitif berkelanjutan (Pratono, Darmasetiawan, Yudiarso, \& Jeong, 2019) 


\section{References}

Harymawan, I., Agustia, D., Nasih, M., Azmi Inayati, \& Nowland, J. (2020). Remuneration Commitees, Executive Remurenation, and Firm Performance. Heliyon, 6(2).

doi:10.1016/j.heliyon.2020.e03452

Madaleno, M., Robaina, M., Ferreira Dias, M., \& Meireless, M. (2019). Dimension Effects in the Relationship Between Eco-Innovation and Firm Performance: A European Comparison. Energy Reports, 6, 631-637.

Osiyevskyy, O., Shirokova, G., \& Ritala, P. (2020). Exploration and Exploitation in Crisis Environment: Implication for Level and Variability of Firm Performance. Journal of Business Research, 114, 227-239.

Pratono, A. H., Darmasetiawan, N. K., Yudiarso, A., \& Jeong, B. G. (2019). Achieving Sustainable Competitive Advantage through Green Enterpreneurial Orientation dan Market Orientaion. The Bottom Line, 32(1), 2-15.

Pratono, H. A. (2016). Strategic Orientation and Information Technological Turbulance: Contingency Perspective. Business Process Management Journal, 22(2), 368-382. 